\title{
TECHNOLOGICAL PARKS IN REGIONAL ENTREPRENEURSHIP ECOSYSTEMS
}

\author{
A. Konarev ${ }^{1 *}$, Sn. Konstantinova ${ }^{2}$ \\ ${ }^{1}$ Technologies and Innovations Corporation PLC - Plovdiv, Bulgaria \\ ${ }^{2}$ Faculty of Economics, University of Food Technologies - Plovdiv, Bulgaria
}

\begin{abstract}
The role of the technology parks for the development of regional entrepreneurial ecosystems is constantly increasing. As centres for updating and technology transfer, these parks directly affect regional systems of business incubators, accelerators, shared jobs, startups and other important elements of entrepreneurial ecosystems. Based on a specific model of a technology park in Plovdiv, the impact and the opportunities for development of the entrepreneurial ecosystem in the South Central Region are explored.
\end{abstract}

Key words: tech park, entrepreneurship, ecosystem, startups, model

\section{INTRODUCTION}

According to a number of authors, the "ecosystem" metaphor is becoming increasingly popular in academia, industry, politics and governance as a means of describing, explaining, promoting and transmitting thoughts, frameworks and views on the interaction of economic agents with the environment (2). There have been studies $(6$, 10), which show that after 2000 the use of concepts "entrepreneurial ecosystem", "business ecosystem" and "innovation ecosystem" have exponential growth. In a spite of that in many cases the term "ecosystem" is applied inconsistently and with a vague definition.

The metaphor "ecosystem" was first used by the ancient Greek philosopher Hesoid (about 700 BC), which describes how resources should be distributed efficiently within households called "oikos" (oikos) where the prefix "eco" originates in "ecology" and "economy" (10). On this basis some authors (6) distinguish three groups of impacts on ecosystems: economic, technological and social. Economic impacts are expressed in

*Correspondence to: Prof. Asen Ivanov Konarev, D.Sc., Technologies and Innovations Corporation PLC - Plovdiv, Bulgaria, 4002, 27A Hristo Botev Blvd., Cell Phone: +359882 933405, E-mail: akonarev@abv.bg increasing local capital wealth and prosperity, as entrepreneurial ecosystems create value. Regional agglomeration of local factors and entrepreneurial resources and their exploitation contribute for sustainability and viability of region. Entrepreneurial ecosystems create competitive advantages and value for individual companies and sectors, increasing regional innovation outcomes (11).

Technological influences are reflected in accelerating regional innovation mechanisms, leading to transformation of ideas and inventions into innovative products and services. In this respect, the existence of a technology park in the regional entrepreneurial ecosystem is crucial for the transfer of technology and boost innovation. The presence of universities and research institutions, as generators of ideas and talents is very important, but the practice shows that where the regional entrepreneurial ecosystem is dominated by a university, the transfer of technology to companies is not at the required level.

Social impacts is related with network effects of cooperation, which are formed between entrepreneurial ecosystem participants such as existing and new enterprises, universities and research organizations, municipal and district administrations, etc. As stated by a number of 
authors (8, 25), while economic and technological dimensions are trying to provide answers to the creation of value in the entrepreneurial ecosystem so the social dimensions are directed to the distribution of this value among members of the ecosystem, not only monetary but also non-monetary results. In this connection social benefits may appear in new products and services for the region, creation of regional added value and a local public good.

Some research shows that regional entrepreneurship development policies currently pass a transition from increasing the amount of entrepreneurship to improve its quality (23). According to Audretsch (6), the concept of entrepreneurial ecosystems has appeared in recent years, as a framework for understanding the nature of the places where entrepreneurship thrives. Spiegel (22) defines the entrepreneurial ecosystem as a combination of social, political, economic and cultural elements in the region that support the development and growth of innovative startups and encourage emerging entrepreneurs and other actors take risks of starting and financing business. By revealing the growing focus of politicians on promoting entrepreneurial ecosystems, Roundy and Fayard define the ecosystem as an interconnected system of forces that generates and sustains regional entrepreneurship (19).

\section{MODELS}

In our view, the regional entrepreneurial ecosystem is a distinct network of regional agents, factors and resources that function as a unified system of connected parts and provide entrepreneurs with strategic and competitive advantages based on shared resources, networking effects, dissemination of knowledge and technology, local donations, public support, and all other elements that affect the value chain of the company, both directly and indirectly.

Determinative in this definition is that the regional entrepreneurial ecosystem is a network, which spatial and virtual boundaries are formed in an information platform (software product) which at the initial stage has to be developed and put into operation by a technology park. As in any entrepreneurial network, as well as in the regional entrepreneurial ecosystem there is cocompetition, which is characterized both by cooperation and by competition, but the effect of cooperation greatly exceeds rivalry competition between entrepreneurs and their companies. In an economic sense, the ecosystem consists of exogenous components, environments and agents acting endogenously and together as a system, generating benefits of interconnection (1-3).

Technological parks have an important role in transferring technology and stimulating economic growth in a regional aspect (15). Their role is constantly growing in connection with the development of the knowledge-based economy. The International Association of Science Parks and Areas of Innovation (IASP) identifies the technology park as an organization run by specialists whose primary goal is to increase the wealth of their community by promoting the culture of the in competitiveness of affiliated enterprises $(4,7$, 9).

Technological parks are very important for the development of the innovativeness of technology companies located in the ecosystem $(13,18,26)$. Basically technological park improves overall performance of all partners in the entrepreneurial ecosystem (20).

World trends show that the role of technology parks is growing in the process of generating new ideas and turning them into new products and services. As a rule generation and deployment of innovations face serious barriers of stereotype enterprise activity. This manifests the field of activity of parks as disruptors of these barriers (17). Constraint on innovation of organizations is defined as factors that inhibit the process of generating new ideas and their realization $(16,21)$. Thanks to shared efficiency, parks must successfully neutralize these barriers. On the one hand, the park should prepare enough good suggestions for companies (12). On the other hand, companies must successfully use the support which park offers. The study of the authors shows that a lot of attempts have been made in Bulgaria to set up parks. 10 years ago in Bulgaria are planned 21 technology parks. At present, their number is reduced to 15 , except in industrial areas such as Plovdiv, Varna, Burgas and others, there are projects for industrial and technological parks in Northwest Bulgaria: Vratsa, Pleven, and Gabrovo. After all, there are only two parks:

- in Sofia - Sofia Tech Park;

- in Plovdiv - Tech Park Optela.

Analysing the specific reasons for unsatisfactory results on establish of 
technology parks has allowed us to distinguish three basic models for their creation:

1. Centralized model.

2. Decentralized model.

3. Mixed model: centralized-dispersion model.

In the centralized model, the state is generally provided with different options the main part of funds for the construction of park. Sometimes it provides property to municipalities for the purpose of the park. Due to the chronic shortage of funds, municipalities are trying to support implementation of the projects with commitments to create engineering infrastructure of the technology park. In rare cases, they are ready to transfer real estate for the purposes of the park. Then administrative pressure forces state universities and other budget structures to enter into associations or foundations with the leadership of the technology park to use the resources of the park.

In the decentralized model, entrepreneurial ecosystems locally appear to be natural integrators of start-ups, freelancers and other self-employed entrepreneurs. This approach is based on the principle of partnership, mutual interest and shared efficiency. The core of the technology park is formed by one or several established technology companies. They provide the initial resources (land, buildings, funds, etc.) and realize the project for the establishment of the technology park. At the first stage, the park starts to operate with relatively limited resources, but mutual interest leads to increasing clustering and increasing the capacity of the technology community. A typical example in this regard is Tech Park Optela.

In centralized model, there is usually a deficiency in efficiency, and in the case of decentralized - resource deficiency. With the mixed model, it is possible to overcome these deficits. It is realized with entrepreneurial communities building the core of the technology park on a decentralized approach. Then they attract regional or territorial state and municipal structures to build appropriate infrastructure around the park, improving marketing and co-ordination, creating incentives and incentives for park entrepreneurs, and so on.

The mixed model significantly improves the strategic management of the technology park and the entire entrepreneurial ecosystem by: development strategy; marketing strategy; a phased implementation strategy; a strategic regulation on rights and obligations; stimulating admission requirements for new businesses; social responsibility; publicity and transparency of activities, etc.

\section{RESULTS AND DISCUSSION}

In our view, the Technology Park has a central role in shaping and developing the regional entrepreneurial ecosystem, as its technology companies and IT and communications specialists will develop the regional platform to define the spatial and virtual boundaries of the network. In this regard, some authors (5) emphasize the great importance of information and communication technologies for the development of entrepreneurial ecosystems. The core infrastructure of the information, communication and, in certain cases, transactions will be the Internet. The regional network will bring together the contributions of multiple stakeholders: public authorities (municipal and district), entrepreneurs, universities and other research organizations, vocational schools, investors, banks and nonbanking financial institutions, nongovernmental organizations, regional resource providers (raw materials, energy, etc.), regional resource users (companies, shops, starters, etc.) and others. There are rules and standards in regional entrepreneurial ecosystem that will be programmed in platform and will be known and respected by network participants.

The Technology Park is the provider of context, who manages the relationship between the participants in regional network and directs value-creating activities. Network participants exchange a variety of information and resources and benefit from synergies.

The main functions of Technology Park for the creation and development of regional entrepreneurial ecosystem can be synthesized in the following way:

1. Creation of new information resources (platforms, conglomerates, portals, etc.) for gravitational potential, formation and development of the ecosystem with the main objective - efficient allocation and use of regional resources.

2. Stimulate technological progress and innovation in the ecosystem by speeding up technology transfer.

3. Reduce the entrepreneurial risk of startups and emerging entrepreneurs by 
preferentially allocating incubator resources (startups, shared jobs, etc.) under the Program "Soft landing".

4. Financial support for scalable technology start-ups and other fast-growing companies through the Park Accelerator.

5. Provision of a complex of services (mentoring, consultancy, legal services, etc.) for the establishment and registration of new firms and the development of existing companies in the ecosystem.

6. Establish and develop relationships with companies and other agents outside the region to support the regional entrepreneurial ecosystem.

7. Development of academic entrepreneurship in cooperation with universities and other scientific organizations from the regional ecosystem.

8. Support the transfer of technology from universities and research organizations to ecosystem companies.

9. Organizing training activities in the field of technology transfer, business entrepreneurship, financing of technological enterprises, etc.

10.Manage the network through the IT platform and develop its functionality until a management body is established (for example, a regional association or other legal form).

The Technology Park should create a set of programs to stimulate ecosystem development, initially offering the following five programs:

A. "Soft landing" Program - symbolic rentals, preferential services, shared jobs and more for starters, freelancers and other ecosystem agents.

B. "Successful start" Program consultancy for innovative idea selection, company registration, intellectual property protection, bid preparation, innovation planning, certification, market analysis and market potential, etc.

C. "Technology transfer" Program search for a specific technology on demand, contact with the supplier or recipient, negotiated technology delivery, help with technology implementation, technology audit, technology deployment monitoring, cooperative mediation abroad, market prototype tests and more.

D. "Development" Program - preferential training in regional universities, colleges, vocational schools, company training centres and ecosystem partners, support for distance learning in Bulgarian or foreign higher schools outside the region, etc.

E. "Health" Program - Preferential services of ecosystem partners in regional sports complexes, fitness centres, health and longevity centres, preferential supply of healthy food supplements from e-shops and other suppliers in the region, etc.

For economic, social, technological and cultural centres such as Stara Zagora whose local leadership has an affinity for regional development, we offer the following model for the formation and development of the regional entrepreneurial ecosystem:

1. The Municipality of Stara Zagora announces a public procurement contract for the development of an IT platform for the regional entrepreneurial ecosystem with the participation of local technology companies (approximate value of the platform: $40000-80000 \mathrm{BGN}$ ).

2. A local technology company or consortium of companies wins the contract and develops such a platform actively looking for and including local suppliers and users of the platform in the original virtual image (demo) of the regional ecosystem.

3. The municipal administration as the owner of platform created Tech Park Stara Zagora Association, which in the initial period invited members of the technology companies, platform developers.

4. If the public administration has unused buildings and areas on the way of the public-private partnership, it provides them with the territory of the Technology Park - so the park will be established as a regional centralized model - Sofia Tech Park.

5. If the public administration does not have such resources, it can stimulate local firms with old industrial buildings, through rational modernization and reconstruction, to rebuild them at a Technology Park model Tech Park Optela.

6. In the centrally dispersed model, the Municipality of Stara Zagora started to invite and encourage participation in platform of local key regional agents, structuring entrepreneurs and their companies; local employers' organizations; local universities; local technology companies, incubators, accelerators and suppliers of legal, advisory, mentoring and other business 
related services; local non-governmental organizations with a relationship to business, ecology, social status, etc.; local suppliers and users of regional economy products and services, etc.

7. Due to the real mutual benefits of shared resources, network effects, science and technology transfer, local donations, public support and all the components, influencing directly or indirectly the value chain, the number of regional actors in the platform will grow exponentially.

8. The Municipality of Stara Zagora can institutionalize its regional entrepreneurial ecosystem in two ways:

Option I - with Technology Park;

Option II - without a Technology Park (if there are no conditions for its creation).

\section{CONCLUSION}

We are convinced that in both options, financial resources can be found from European and national programs for the creation and development of ecosystems.

In terms of worldwide opposing processes, united in the term "globalization", the development of regional entrepreneurial ecosystems with or without a technology park is a proven factor for the economic, social, technological and cultural development of the regions.

\section{REFERENCES}

1. Acs, Z. J., Andretsh, D., Lehmann, E. and Licht, C., National system of entrepreneurship. Small Business Economics, 46 (4), pp. 527-535, 2016.

2. Acs, Z. J., Stam, E., Audretsch, D. B. and O'Connor, A., The lineages of the entrepreneurial ecosystem approach. Small Business Economics, (1), pp. 1-10, 2017.

3. Acs, Z., Andretsh, D., Lehmann, E. and Licht, C., National system of innovation. Journal of Technology Transfer, 42 (5), pp. 997-1008, 2016.

4. Almedia, A., Santos, C. and Silva, M. R., Bridging Science to Economy: The Role of Science and Technologic Parks in Innovation Strategies in "Follower" Region. Faculty of Economics Working Paper 302, University of Porto, Porto, 2008.

5. Andonova, V., Nicolova, M. and Dimitrov, D., Entrepreneurial Ecosystems in Unexpected Places: Examining the Success Factors of Regional Entrepreneurship, 2019. - https://www.palgrave.com/gp/book

6. Audretsch, D., Cunningham, J., Kuratko, D., Lehman, E. and Menter, M.,
KONAREV A., et al.

Entrepreneurial ecosystem: economic, technological and social impacts. In: The Journal of Technology Transfer, April 2019, Volume 44, Issue 2, pp. 313-325, 2018. - https://doi.org/10.1007/s10961018-9690-4

7. Cantú, Ch., Exploring the Role of Spatial Relationship to Transform Knowledge in a Business Idea - Beyond a Geographic Proximity. Industrial Marketing Management 39, pp. 887-897, 2010

8. Clarysse, B., Wright, M., Bruneel, J., Mahajan, A., Creating value in ecosystems: Crossing the chasm between knowledge and business ecosystem. Research Policy, 43 (7), pp. 1164-1176, 2014.

9. Closs, L., Ferreira, G. C., Soria, A. F., Sampaio, C. H. and Perin, M., Organizational Factors that Affect the University-Industry Technology Transfer Processes of a Private University. Journal of Technology Management and Innovation 7 (1), pp. 104-117, 2012.

10.Colombo, M. G., Dagniro, G. B., Lehmann, E. E., Salmador M. P., The governance of entrepreneurial ecosystems. Small Business Economics, 2017. https://doi.org/10.1007/s11187-017-9952-9

11.Cunningham, J. A., Menter, M., O'Kane, C., Value creation in the quadruple helix: A micro level conceptual investigators as value creators. $R \& D$ Management, 48 (1), pp. 136-147, 2018.

https://doi.org/10.1111/radm.12310

12.Durão, D., Salmento, M., Varela, V. and Maltez, L., Virtual and Real-estate Science and Tehnology Parks: A Case Study of Taguspark. Tehnovation, Vol. 25 (3): pp. 237-244, 2005.

13. Hartung, V., MacPherson, A., Innovation and Collaboration in the Geographic Information Systems (GIS) Industry: Evidence from Canada and the United States. $R \& D$ Managemet 30 (3): pp. 225234, 2000.

14.Kerpacz - A. W. and Mazurkjewicz, S., Practices of Technology Parks Supporting Innovative Activities: Evidence from Poland. Managing Global Transitions, Vol. 13 (4), pp. 331-354, 2015.

15.Konstantinova, Sn. and Konarev. A., The Technological Parks and the Development of Industrial Companies. In: International Scientific and Practical Conference "Opportunities for Business Development Economic, Managerial and Social Dimensions". SA "D. A. Tsenov" - 
Svishtov, 2018, Volume I, pp. 158-167, 2018.

16. Mirow, C., Hoelzle, K. and Gemuenden, H. G., The Ambidextrous Organization in Practice: Barriers to Innovation within Research and Development. Paper presented at the Academy of Management Annual Meeting, Anaheim, CA, pp. 8-13, August 2008.

https://www.researchgate.net/publication/2 76050598

17.Musyck, B. and Reid, A., Innovation and Regional Development: Do European Structural Funds make a Difference? European Planning Studies, Volume 15 (7): pp. 961-983, 2007.

18.Nieto, M. J. and Santamaria, L., The Importance of Diverse Collaborative Networks for the Novelty of Product Innovation. Technovation, Vol. 27, n. 6-7: pp. 367-377, 2007.

19.Roundy, P., Fayard, D., Dynamic Capabilities and Entrepreneurial Ecosystems: The Micro-Foundations of Regional Entrepreneurship, $2018 . \quad-$ https//doi.org/10.1177/0971355718810296.

20.Sampson, R. C., R\&D Alliances and Firm Performance: The Impact of Technological Diversity and Alliance Organization on Innovation. Academy of Management Journal, Vol. 50 (2): pp. 364-386, 2007.

21.Sandberg, B. and Stenroos - L.A., What Makes it so Difficult? A Systematic Review
KONAREV A., et al. on Barriers to Radical Innovation. Industrial Marketing Management, Vol. 43 (8): pp. 1293-1305, 2014.

22. Spigel, B., The Relation Organization of Entrepreneurial Ecosystems. 2017 https://journal.sagepub.com/doi/pdf/10.111 1/etap12167

23.Stam, E., Entrepreneurial Ecosystem and Regional Policy: A Sympathetic Critique. European Planning Studies 23(9):September 2015. https://www.researchgate.net/publication/2 80243567

_Entrepreneurial_Ecosystems_and_Regional_ Policy_A_Sympathetic_Critique

24.Vargo, S. L., Akaka, M.A., Value cocreation and service system (Re) Formation: A service ecosystems view. Service Science, 4 (3), pp. 183-294, 2012. https://doi.org/10.1287/serv.1120.0019

25.Vargo, S., Lusch, R., (2010). From repeat patronage to value co-creation in service ecosystems: A transcending conceptualization of relationship. Journal of Business Market Management, 4 (4), pp. 169-179.

26. Yang, C. - H., Motohashi, K. and Chen, J.R., Are New Technology - Based Firms Located on Science Parks Really More Innovative? Evidence from Taiwan. Research Policy 38, (1): pp. 77-85, 2009. 